Jnl of Ecclesiastical History, Vol. 73, No. 2, April 2022. (C) The Author(s), 2022. Published by Cambridge University Press. This is an Open Access article, distributed under the terms of the Creative Commons Attribution licence (https://creativecommons.org/licenses/by/4.o/), which permits unrestricted re-use, distribution, and reproduction in any medium, provided the original work is properly cited. doi:10.1017/SoO22046921000683

\title{
Hobbes's Eschatology and Scriptural Interpretation in Leviathan
}

\author{
by TAKUYA OKADA \\ Daito Bunka University, Tokyo \\ E-mail: okada-t@ic.daito.ac.jp
}

Hobbes's eschatology in Leviathan is one of the most striking aspects of this classic work and has received considerable scholarly attention. Nevertheless, its scriptural interpretation has rarely been examined. This article closely analyses Hobbes's scriptural case for two aspects of eschatology: the doctrine of mortalism and the terrestrial kingdom of God. It shows that, to a large extent, Hobbes's biblical exegesis for these two eschatological issues was preceded by that of his contemporaries, including Richard Overton and John Archer. It is likely, in particular, that the scriptural interpretation for Hobbes's mortalism was directly indebted to Overton's Mans mortalitie. obbes's eschatology in Leviathan is one of the most conspicuous aspects of this classic work, drawing the comments of both his contemporaries and modern scholars. ${ }^{1}$ In his view, the kingdom of God after the Resurrection will not be located in heaven but on earth. ${ }^{2}$

I would like to thank Roger Crisp, Jon Parkin, Noel Malcolm and the anonymous reader for their helpful comments and suggestions on earlier drafts of this article. I am also grateful to Kei Nasu for his useful advice. This work was made possible by my appointment to a JSPS Overseas Research Fellowship held at the University of Oxford in $2017-$ 19, and was supported by JSPS KAKENHI Grant Number 19 K23177.

${ }^{1}$ For a few contemporary commentaries see S. Ward, A philosophicall essay, Oxford ${ }_{1652}$ (Wing W.823), sig. A3r; H. Hammond, A letter of resolution to six quaeres, of present use in the Church of England, London $165^{2}$ (Wing H.545), 384; and T. Tenison, The creed of Mr. Hobbes examined in a feigned conference between him and a student in divinity, London 1670 (Wing T.691), 89. J. G. A Pocock was one of the first modern commentators on Hobbes's eschatology: 'Time, history, and eschatology in the thought of Thomas Hobbes', in his Politics, language, and time: essays on political thought and history, London 1972, $14^{8-201 .}$

${ }^{2}$ T. Hobbes, Leviathan, ed. N. Malcolm, Oxford 201 2, ch. xxxviii, pp. 240-1, 246-7. Unless otherwise mentioned, references to Leviathan are given by chapters and page numbers in the first $16_{5}$ 1 edition; these page numbers are found in Malcolm's edition. 
The place for the reprobate, similarly, will not be in everlasting fire or underground but on earth. ${ }^{3}$ The Fall of Adam rendered human beings mortal, and the conventional view that human souls separated from the body will live eternally is wrong. 4 After the last judgement, only the elect will live eternally, while the reprobate will not be eternally punished but suffer a second death. ${ }^{5}$ In his earlier work, De cive, Hobbes barely discussed eschatological issues, let alone presenting such a striking eschatology. ${ }^{6}$ Why, then, did he begin to develop it for the first time in Leviathan? Moreover, how did he come up with it?

These questions have been considered in several ways. One approach is to consider Hobbes's eschatology as part of his project to rewrite Christianity to align more closely with his materialistic philosophy.7 Another is to explore the way Hobbes's eschatology promotes his aim in Leviathan to defend sovereign power and civil peace. ${ }^{8}$ Still another is to place it in the context of the controversies over eschatological issues that took place in the revolutionary years. 9

Despite these approaches, however, an important aspect of Hobbes's eschatology has been largely neglected in previous studies, that is, his scriptural interpretation. While Hobbes's overall method of biblical exegesis in Leviathan has been discussed in several articles, ${ }^{10}$ his specific way of drawing this peculiar eschatology out of the Scriptures against the background of contemporary interpretative practices has been left understudied.

An important exception to the rule is a recent article by Paul Davis, which points out that Hobbes's several readings of biblical verses were, in

3 Ibid. ch. xxxviii, pp. $243-4$.

4 Ibid. p. 238 ; ch. xliv, p. 339 .

5 Ibid. ch. xxxviii, pp. $244^{-5}$.

${ }^{6}$ Idem, De cive: the Latin version entitled in the first edition Elementorum philosophia sectio tertia de cive, and in later editions Elementa philosophica de cive, ed. H. Warrender, Oxford 1983, xvii.5, 13, 28. In citing this work, the following translated version is used: T. Hobbes, On the citizen, ed. and trans. R. Tuck and M. Silverthorne, Cambridge 1997.

7 A. Martinich, The two gods of Leviathan: Thomas Hobbes on religion and politics, Cambridge 1992, 265-6; J. R. Collins, In the shadow of Leviathan: John Locke and the politics of conscience, Cambridge 2020, 95-6.

8 C. McClure, 'Hell and anxiety in Hobbes's Leviathan', Review of Politics lxxiii (201 1), 1-27; D. Johnston, 'Hobbes's mortalism', History of Political Thought x (1989), 655-63.

9 R. Tuck, 'The civil religion of Thomas Hobbes', in N. Phillipson and Q. Skinner (eds), Political discourse in early modern Britain, Cambridge 1993, 131-7; J. Overhoff, Hobbes's theory of the will: ideological reasons and historical circumstances, Lanham, MD 2000, 192-201.

${ }^{10}$ A. Pacchi, 'Hobbes and biblical philology in the service of the state', Topoi vii (1988), 231-9; J. Farr, "Atomes of Scripture": Hobbes and the politics of biblical interpretation', in M. G. Dietz (ed.), Thomas Hobbes and political theory, Lawrence, Ks 1990, 172-96; P. Schröder, 'Die Heilige Schrift in Hobbes' Leviathan: Strategien zur Begründung staatlicher Herrschaft', in D. Hüning (ed.), Der lange Schatten des Leviathan: Hobbes' politische Philosophie nach 35o Jahren, Berlin 2005, 179-99. 
all probability, derived from those of Joseph Mede, a renowned bible scholar and millennialist whom Hobbes mentioned in his later work. ${ }^{11}$ In relation to Hobbes's eschatology, Davis argues that the way in which Hobbes associated the names of the place of the damned with events or places in the Old Testament corresponds well with Mede's approach. ${ }^{12}$

Drawing on Davis's insight, I will turn to two other eschatological issues about which similarities between Hobbes and his contemporaries have been suggested: mortalism, the idea that both body and soul are destroyed at death, and the kingdom of God on earth after the Resurrection. I will conduct a close analysis of Hobbes's use of the Bible regarding these two issues in relation to that of his contemporaries.

The analysis will, first, establish that Hobbes's mortalism is likely to have been directly indebted to Mans mortalitie, the notorious work on mortalism by the future Leveller leader Richard Overton. Previous studies have already shown that Hobbes's mortalism had precedents or contemporary parallels, including in Overton's work. ${ }^{13}$ However, remarks on the similarities between Hobbes and Overton have remained only suggestive due to Hobbes's reluctance to mention his sources. While definite contextual evidence indicating Hobbes's knowledge of Overton's work is not available, a close analysis of textual evidence will show that, among the works of several controversialists on mortalism, only Overton's proof-texts and relevant scriptural interpretation overlap considerably with those in Leviathan. Thus, this article will substantiate the important but disputable claim of Overton's influence on Hobbes.

Second, this paper will turn to the issue of the terrestrial kingdom of God after the last judgement and maintain that elements of Hobbes's scriptural interpretation in support of this view can to a large extent be found in the work of his contemporaries. Jürgen Overhoff has already pointed out that a view similar to Hobbes's was indicated by his contemporary John (Henry) Archer, who envisaged the political kingdom of Christ abiding on earth for a thousand years at the end of this world. ${ }^{14}$ Nevertheless, Overhoff only presented Hobbes's and Archer's views of the kingdom of God without making a close comparison between their readings of the Bible. This article, then, will clarify which aspect of Hobbes's scriptural interpretation in support of the terrestrial kingdom of God was preceded by Archer. It will also take into account another exponent of Christ's personal rule on earth, Robert Maton. While the similarities between Hobbes and Overton are substantial enough to suggest the strong possibility of Overton's influence on

${ }^{11}$ P. B. Davis, 'Devil in the details: Hobbes's use and abuse of Scripture', in L. van Apeldoorn and R. Douglass (eds), Hobbes on politics and religion, Oxford 2018, 146.

12 Ibid.

13 N. T. Burns, Christian mortalism from Tyndale to Milton, Cambridge 1972, 149-91; Overhoff, Hobbes's theory, $195^{-6 .}$

14 Overhoff, Hobbes's theory, 199-201. 
Hobbes, those between Hobbes and Archer or Maton are only partial. However, this article argues that, taken as a whole, many elements of Hobbes's scriptural interpretation in defence of the terrestrial kingdom of God were preceded by the work of Archer and Maton.

While this study cannot, as Paul Davis does, provide definite circumstantial evidence of Hobbes's knowledge of the works of the contemporaries under discussion, it strengthens the case that the publication of works presenting new biblical exegesis during the revolutionary years was an important factor in the development of Hobbes's new eschatology in Leviathan. It also helps to clarify which elements of Hobbes's biblical exegesis in his eschatology were truly peculiar to him.

\section{Hobbes's mortalism}

Although Hobbes's eschatology as a whole was nothing like that of other thinkers, Hobbes's mortalism, at least, is known to have had contemporary parallels. In particular, Norman Burns makes the important claim that 'most of his [Hobbes's] proof-texts and some of his interpretation of them are the same as those of Milton and Overton'. ${ }^{15}$ However, Burns maintains that, in his work against mortalism, 'Calvin conveniently cites and discusses most of the scriptural texts used by both sides in the next century of dispute. ${ }^{16}$ Moreover, Burns mentions several controversialists on the doctrine of mortalism during the Civil War other than Hobbes and Overton. ${ }^{17}$ Given Hobbes's lack of reference to his sources, remarks on the similarities between Hobbes and Overton, or any other contemporary for that matter, have only pointed to potential sources without an adequate foundation. However, it is possible to substantiate the useful but questionable claim of Overton's influence on Hobbes by a close analysis of scriptural interpretation, in particular the proof-texts used by Hobbes and others for or against the doctrine of mortalism. This paper will show the significant similarity between Hobbes and Overton among Hobbes's contemporaries concerning the citation and reading of scriptural passages, noting that this extent of similarity is rarely found between Hobbes and Calvin or any other contemporary writer, such as Milton, on the immortality of the soul. ${ }^{18}$

15 Burns, Christian mortalism, 185 . The similarity between Hobbes's use of the Bible and Overton's is also noted by Overhoff, Hobbes's theory, 196.

${ }_{16}$ Burns, Christian mortalism, 22.

${ }^{17}$ Ibid. $148-91$.

18 Milton's work proposing the doctrine of mortalism, De doctrina christiana, was not published at that time and was thus unknown to his contemporaries, including Hobbes. Bryan Ball notes that Milton's mortalism probably had little influence on his contemporaries: The soul sleepers: Christian mortalism from Wycliffe to Priestley, Cambridge 2008, 115 . Nevertheless, this article will take Milton into consideration, as it will show that 
For the sake of clarity, it should be noted that in England in the middle of the seventeenth century, the issue of mortalism was discussed on the basis of natural reason and the Bible. Some, such as Kenelm Digby and Seth Ward, used only philosophical arguments, ${ }^{19}$ while others, such as Overton, Alexander Ross and Guy Holland, used both types of arguments. ${ }^{20}$ The focus here, however, is on biblical cases.

The most significant similarity between Hobbes and Overton concerns the citation and interpretation of scriptural passages. In discussing the doctrine of mortalism in chapters xxxviii and xliv, Hobbes cited numerous scriptural passages, most of which were also quoted by Overton. First, in defence of mortalism, Hobbes cited four passages (Genesis ii.17; Romans v.18-19; 1 Corinthians xv.21-2; Job xiv.7-12) in chapter xxxviii of Leviathan and three (Ecclesiastes iii.19; iv.3; ix.5) in chapter xliv. ${ }^{21}$ Of these seven scriptural verses, six were cited by Overton to support the doctrine of mortalism. ${ }^{22}$ Overton did not cite Rom. v.18-19, 'As by the offence of one judgment came upon all men to condemnation; even so by the righteousness of one the free gift came upon all men unto justification of life', as Hobbes did. ${ }^{23}$ However, Overton did cite 1 Cor. Xv. $21-2$, 'For since by man came death, by man came also the resurrection of the dead. For as in Adam all die, even so in Christ shall all be made alive', which was a more clearly articulated version of Rom. v.18-19 in Hobbes's view. ${ }^{24}$ The two men's interpretations of this passage were also similar. Just after citing this passage, Overton said, 'What fell in Adam shall be raised by Christ; what

even with a view to Milton, the correspondence between Hobbes and Overton is striking. Although Burns points out that Hobbes's mortalism was close to those of Overton and Milton, he does not clarify which of the two was closer: Christian mortalism, ${ }^{183}-5$. See also N. H. Henry, 'Milton and Hobbes: mortalism and the intermediate state', Studies in Philology xlviii (1951), 234-49, and P. C. Almond, Heaven and hell in Enlightenment England, Cambridge 1994, 47-54.

${ }^{19} \mathrm{~K}$. Digby, Two treatises in the one of which the nature of bodies, in the other, the nature of mans soule is looked into in way of discovery of the immortality of reasonable soules, Paris 1644 (Wing D.1448); Ward, A philosophicall essay, 33-74. To these may be added Thomas Browne, though his remarks are quite succinct: Religio medici, and other works, ed. L. C. Martin, Oxford 1964, 7-8. While Digby and Ward defended the immortality of the soul, Browne called it into question.

${ }^{20}$ R. Overton, Mans mortalitie, ed. H. Fisch, Liverpool 1968; [H. Guy], The prerogative of man, Oxford 1645 (Wing P.3220); A. Ross, The philosophicall touch-stone: or, Observations upon Sir Kenelm Digbie's discourses of the nature of bodies and of the reasonable soule, London 1645 (Wing R.1979). Unlike Overton, however, Guy and Ross supported the immortality of the soul.

${ }^{21}$ Hobbes, Leviathan, ch. xxxviii, pp. 239-41; ch. xliv, pp. 343-4.

${ }_{22}$ Overton, Mans mortalitie, 7 (Gen. ii.1 7), 9 (1 Cor. Xv.2 1-2), 12 (Job xiv.7-12), 14 (Eccl. iii.19), 17 (Eccl. iv.3, ix.5).

${ }^{23}$ Unless otherwise noted, I follow the wording of the King James Version (KJV) in citing scriptural verses.

${ }^{24}$ Overton, Mans mortalitie, 9; Hobbes, Leviathan, ch. xxxviii, p. 239. 
was mortalized by the earthly Man shall be immortalized by the Heavenly man.' ${ }^{25}$ Similarly, Hobbes commented on the passage that 'Eternall life was lost by Adams forfeiture, in committing sin, he that should cancell that forfeiture was to recover thereby, that Life again. ${ }^{2} 6$

Controversialists other than Overton also referred to some of the seven scriptural passages Hobbes quoted in support of mortalism, but not as many as Overton did. Milton, another mortalist, quoted two scriptural passages (1 Cor. xv.21; Job xiv.7-12). ${ }^{27}$ Guy and Ross, opponents of mortalism, presented three passages (Eccl. iii.19; 1 Cor. xv.22; Job xiv) as proof-texts allegedly supporting Overton's mortalism. ${ }^{28}$ In addition, Calvin cited three passages (Gen. ii.17; Job xiv.7-12; Eccl. iii.19) as ones that his opponents emphasised. ${ }^{29}$ Some of Hobbes's citation of prooftexts for mortalism, therefore, was conventional in the long-running controversy over Christian mortalism. The extent of the similarity between Hobbes and Overton, however, was significant even in this tradition.

Hobbes not only referred to scriptural verses supporting mortalism but also cited and discussed those apparently against mortalism. One such scriptural passage that Hobbes discussed in chapter xxxviii was Luke xx.37-8.30 In chapter xliv he handled Eccl. xii.7 and the case of Enoch, who was translated so that he would not die, with citations of Gen. v.24 and Hebrews xi. $5^{.3^{1}}$ Additionally, in chapter xliv, without quoting specific scriptural verses, he mentioned and addressed Christ's remark that Abraham, Isaac and Jacob were living and the story of Lazarus, who, upon his death, was carried into Abraham's bosom. ${ }^{32}$

Here again, Hobbes and Overton were much more alike than were Hobbes and the other controversialists considered in this paper. Before Hobbes, Overton had already dealt with all five of the issues or scriptural verses that Hobbes addressed.33 Hobbes's and Overton's interpretive approaches to these passages were also alike in some cases. For example,

25 Overton, Mans mortalitie, 9 .

${ }^{26}$ Hobbes, Leviathan, ch. xxxviii, p. 238.

27 J. Milton, The complete works of John Milton, VIII: De doctrina christiana, ed. J. K. Hale and J. D. Cullington, Oxford 201 2, 440-1 (1 Cor. xv.21), 442-3 (Job xiv.10, 12).

${ }_{28}$ [Guy], The prerogative of man, 8 (Eccl. iii.19), 42 (1 Cor. xv.22); Ross, The philosophicall touch-stone, 118 (Eccl. iii.19; Job xiv), 123-4. Burns notes that Eccl. iii.19 'was doubtless a favorite with those who denied the immortality of the soul': Christian mortalism, 29.

${ }^{29}$ J. Calvin, Tracts, iii, trans. H. Beveridge, Edinburgh 1851, 453 (Gen. ii.1 7), 457-8 (Job xiv.7-12), 46o (Eccl. iii.18-21). Though in different contexts, he also referred (pp. 439, 456) to 1 Cor. xv.21-2 and Rom. v.17, next to Rom. v.18-19.

$3^{\circ}$ Hobbes, Leviathan, ch. xxxviii, p. 240 . $\quad 3^{1}$ Ibid. ch. xliv, p. 343-4.

$3^{2}$ Ibid. p. 344. Malcolm, in a note in his critical edition, suggests Matt. viii.1 1, Luke xiii.28, and xvi.19-31 as relevant passages: Hobbes, Leviathan, ch. xliv, p. 989. (Malcolm edn).

33 Overton, Mans mortalitie, 16 (Luke xx.37-8 and the issue of a living Abraham, Isaac and Jacob), 54 (Eccl. xii.7), 47 (the case of Enoch in Heb. xi.5), and 55 (the story of Lazarus). 
both Hobbes and Overton treated the story of Lazarus as a 'parable'.34 More significant was a parallel interpretation of Christ's remark in Luke xx.37-8: 'That the dead are raised, even Moses shewed at the bush, when he calleth the Lord the God of Abraham, and the God of Isaac, and the God of Jacob. For he is not a God of the dead, but of the living; for all live unto him.' Both Hobbes and Overton, noting that this remark of Christ was meant to prove the Resurrection, referred to the possibility of reading this passage as a proof-text for the immortality of the soul.35 They then rejected this reading by pointing out that it would entail the remark of Christ not proving what it was meant to prove, the Resurrection.

Certainly, some of Hobbes's interpretations of biblical passages that seemed against mortalism could be found in the works of others. According to Calvin, for example, his opponents, like Hobbes, read the story of Lazarus as a parable and regarded the remark of Christ about a living Abraham and others as the promise of Christ. ${ }^{6}$ Milton addressed Eccl. xii.7 and Luke xx.37, giving an interpretation of Luke xx.37 similar to those of Hobbes and Overton.37 Guy and Ross emphasised the matter of a living Abraham, Isaac and Jacob as well as the story of Lazarus. $3^{8}$ Thomas Hooker cited Eccl. xii.7.39 None the less, the extent of the similarity between Hobbes and Overton was unparalleled.

In addition to the common use and interpretation of proof-texts, Hobbes's interpretation of 1 Cor. xv.42-3, as part of his attempt to deny the reprobate an eternal life, can be understood as his reply to Overton's reading. In Hobbes's view, the passage, 'It [the body, according to the wording of Hobbes] is sown in corruption; it is raised in incorruption: It is sown in dishonour; it is raised in glory: it is sown in weakness, it is raised in power', might be interpreted to mean that not only the faithful but also the reprobate will have eternal life after the Resurrection. $4^{\circ}$ Actually, this was the position of Overton, who cited only 1 Cor. Xv.42, 'It is sowne in corruption, it is raised in incorruption', to present the signifi-

34 Hobbes, Leviathan, ch. xliv, p. 344; Overton, Mans mortalitie, 55.

35 Hobbes, Leviathan, ch. xxxviii, p. 240; Overton, Mans mortalitie, 16.

$3^{6}$ Calvin, Tracts, 430-5, 444-5. Ross also mentions the story of Lazarus in his criticism of mortalism, though he was not aware of the kind of counter-argument that Hobbes deployed: Medicus medicates: or, The physicians religion cured by a lenitive or gentle potion, London 1645 (Wing R.1961), $5^{\mathrm{O}-1 .}$

37 Milton, De doctrina christiana, 444-5 (Luke xx.37), 452-3 (Eccl. xii.7). Note that in the text, Milton mentions Eccl. xii.9 in the Junius-Tremellius-Beza Bible, the equivalent of Eccl xii. 7 in the KJV.

$3^{8}$ Guy, The prerogative, sig. A2v (Matt. xxii.32), 9 (Eccl. xii); Ross, The philosophicall touch-stone, 108-9 (Matt. xxii.32; Luke xvi; Eccl. xii).

39 T. Hooker, The immortality of mans soule, proved both by Scripture and reason, London 1645 (Wing I.57), 45 .

$4^{\circ}$ Hobbes, Leviathan, ch. xxxviii, p. 244. 
cance of the Resurrection as a change into 'an everlasting Being'.$^{11}$ Against such an interpretation, Hobbes pointed out that it was inconsistent with the terms in the next verse, 'glory' and 'power', which could be attributed only to the faithful. $4^{2}$

Apart from the use and interpretation of proof-texts, another remarkable correspondence between Hobbes and Overton concerns the structure of their arguments. When Hobbes presented his scriptural exegesis in defence of the doctrine of mortalism at the beginning of chapter xxxviii of Leviathan, the sequence of biblical topics that he handled was as follows: the eternal life that Adam, free from sin, enjoyed in the beginning; Adam's Fall and the change of human beings from immortal into mortal creatures; and the effect of the atonement of Jesus Christ.43 These topics were discussed in this same sequence at the beginning of Mans mortalitie.44 Moreover, both Hobbes and Overton quoted Gen. ii.1 7 , 'In the day that thou eatest thereof thou shalt surely die', for the change into mortality, and 1 Cor. xv.22, 'For as in Adam all die, even so in Christ shall all be made alive', for the atonement of Christ. 45

Lastly, Hobbes and Overton also shared their treatment of the word 'soul' in the Scriptures. ${ }^{6}$ Usually, the human soul was thought to be a substance. Hobbes's remark in The elements of law that 'the soul of man is a spirit' and immortal was an expression of this conventional idea. 47 In Leviathan, however, he began to see the 'soul' in the Scriptures not as a distinct substance but simply as 'the Life', 'the Living Creature' or 'the Body alive', which reflected his new philological examination of 'spirit' in chapter xxxiv. $4^{8}$ Overton also offered several meanings of the term 'soul' as it is used in the Bible, including 'life', to deny the interpretation of 'soul' as a substance. 49

This treatment of 'soul', certainly, can be traced back to the age of Calvin. Calvin presented his reading of several key words to defend his view of the immortality of the human soul against the views of his opponents. $5^{\circ}$ One of his opponents claimed that the 'soul' referred to in the Bible was nothing but life (or living creatures), precisely the view that would later be adopted by Hobbes. $5^{1}$ Moreover, apart from Calvin, the contemporary mortalist Milton characterised the 'soul' as the animated body or the whole man, rejecting an understanding of the 'soul' as a

$4^{1}$ Overton, Mans mortalitie, 9, 36. Here, the wording of Overton is used for 1 Cor. xv.42. $\quad 4^{2}$ Hobbes, Leviathan, ch. xxxviii, p. 244. $\quad{ }^{43}$ Ibid. pp. $23^{8}-9$.

44 Overton, Mans mortalitie, 7-9.

45 Hobbes, Leviathan, ch. xxxviii, p. 238-9; Overton, Mans mortalitie, 7, 9.

$4^{6}$ For this see also Burns, Christian mortalism, $175^{-6,1} 8_{5}$.

47 T. Hobbes, The elements of law, natural and politic, London 1969, i.11.5.

$4^{8}$ Idem, Leviathan, ch. xliv, pp. 339-40; ch. xxxiv, p. 209.

49 Overton, Mans mortalitie, $33-5,54-5$. The specific catalogues of the words 'soul' and 'spirit' differed between Hobbes and Overton, however.

$5^{\circ}$ Calvin, Tracts, $420-7$.

$5^{1}$ Ibid. 420 . 
substance separable from the body. $5^{2}$ Nevertheless, it appears that, apart from mortalists such as Overton and Milton, no other writer on the soul's immortality in the 1640 s mentioned this interpretation of the 'soul' in the Scriptures.

Now that the textual evidence for the probable influence of Overton's Mans mortalitie on Hobbes has been adduced, it may be useful to give some consideration to the possible contextual link between Hobbes and Mans mortalitie, despite the limited available evidence. The first thing to observe is that even during his sojourn in Paris, Hobbes had access to some works published in England during the revolutionary years. Despite Hobbes's general lack of explicit reference in Leviathan to contemporary authors or texts, 53 at least three contemporary authors whose works were published in England between $164^{\circ}$ and $16_{5^{\circ}}$ have been identified confidently as Hobbes's source or the object of his implicit references: Joseph Mede, Anthony Ascham and Marchamont Nedham.54 This indicates that, even in Paris, Hobbes could read contemporary works published in England.

The next point is that Hobbes knew, in Paris, an author of a work on the immortality of the soul: Kenelm Digby. Digby, a natural philosopher, had been acquainted with Hobbes since at least the ${ }_{16} 6_{3}$ os. After the outbreak of the Civil War, he left for France, where he renewed his friendship with Hobbes between 1643 and 1645.55 A member of the Blackloist group, he was also familiar with Thomas White, whose work published in $1642, D e$ mundo, prompted Hobbes to write an extensive manuscript refutation, known as Anti-White, around $1642-3.5^{6}$ In 1644 Digby published his major work, Two treatises, the second part of which was devoted to demonstrating the immortality of the soul.57 Given the friendship between

$5^{2}$ Milton, De doctrina christiana, 302-3. This agreement between Hobbes and Milton is often noted. See, for example, Ball, The soul sleepers, 109. Jeremy Taylor, who expressed an opinion that came close to the doctrine of mortalism, also presented an understanding of 'soul' similar to Milton's. For Taylor, the soul in the Scriptures signified 'an essential part of man, relating to his whole constitution' rather than 'of it self an intellectual and separate substance': The great exemplar of sanctity and holy life, London 1649 (Wing T.342), iii. 178.

53 For Hobbes's scanty references to modern texts see Hobbes, Leviathan, i. 107-8.

54 Ibid. 68-72; Davis, 'Devil in the details', 146.

55 T. Hobbes, The correspondence of Thomas Hobbes, ed. N. Malcolm, Oxford 1994, ii. $829-30$.

$5^{6}$ J. Henry, 'Atomism and eschatology: Catholicism and natural philosophy in the Interregnum', British Journal for the History of Science xv (1982), 211 1-39. On Hobbes and the Blackloists see J. R. Collins, 'Thomas Hobbes and the Blackloist conspiracy of 1649', HJxlv (2002), 305-31.

57 Digby, Two treatises. This work established Digby's reputation as a natural philosopher. See M. Foster, 'Sir Kenelm Digby', ODNB. 
Hobbes and Digby, it is likely that Hobbes knew this work and took an interest in the theme of the immortality of the soul. $5^{8}$

Mans mortalitie had an enormous impact in England at the time of its publication in 1643.59 Soon after its publication, the work was discussed in the Westminster Assembly, and the doctrine of mortalism was taken up in the parliament. ${ }^{6 o}$ In the Blasphemy Ordinance of 1648 , espousing the doctrine of mortalism became a punishable crime ${ }^{61}$ Furthermore, the doctrine of mortalism, together with Mans mortalitie, was mentioned as one of the 'heresies' emerging at that time in the major works of heresiography in the 164 os. $^{62}$

It should be noted, however, that the author of Mans mortalitie was not known to contemporary readers. Sources of the day often mentioned this work without specifying its author. The author of Mans mortalitie, moreover, was sometimes misidentified. In the Westminster Assembly, for example, the doctrine of mortalism was associated with the Independent minister John Goodwin. ${ }^{63}$ Even Thomas Edwards, the author of Gangraena, the then-famous heresiography, did not identify the author of Mans mortalitie as Richard Overton, at least not explicitly. In this work, certainly, he both mentioned Mans mortalitie and recognised Overton as one of the Leveller leaders. ${ }^{64}$ In part II of Gangraena, he reported about 'one Overton' who was involved in a dispute over the immortality of the soul, though it is not entirely clear whether this 'Overton' was actually Richard Overton. ${ }^{6} 5$ However, in part I of Gangraena, Edwards wrongly assumed that

$5^{8}$ Note, however, that unlike Hobbes, Digby did not provide any scriptural exegesis.

59 For this see also Burns, Christian mortalism, 124-42.

60 Westminster Assembly, The minutes and papers of the Westminster Assembly, I643I652, ed. C. B. Van Dixhoorn and others, Oxford 2012, iii. 260; v. 88; Journal of the House of Commons, III: I643-I644, 606, 694, 697; E. Calamy, An indictment against England because of her selfe-murdering divisions, London 1645 (Wing C.256), 13 .

61 'May 1648: An ordinance for the punishing of blasphemies and heresies, with the several penalties therein expressed', in C. H. Firth and R. S. Rait (eds), Acts and ordinances of the Interregnum, I642-I660, London $1911,1133^{-6}$. For a detailed examination of the controversy surrounding the Blasphemy Ordinance see S. Mortimer, Reason and religion in the English Revolution: the challenge of Socinianism, Cambridge 2010, 180-4, and J. Coffey, John Goodwin and the Puritan revolution: religion and intellectual change in seventeenth-century England, Woodbridge 2006, 141-7, 165 .

${ }^{62}$ T. Edwards, Gangraena: or, A catalogue and discovery of many of the errours, heresies, blasphemies, London ${ }_{1646}$ (Wing E.228), 26-7; D. Featley, Katabaptistai kataptystoi: the dippers dipt, London 1645 (Wing F.586), sig. B2v; E. Pagitt, Heresiography: or, A discription of the hereticks and sectaries of these latter times, 2nd edn, London 1645 (Wing P.175), sig. [A]v, pp. 139-41; Anon, A testimony to the trueth of Jesus Christ, and to our solemn league and covenant, London 1648 (Wing T.823), 19-21.

63 Westminster Assembly, Minutes and papers, iii. 260.

64 See also A. Hughes, Gangraena and the struggle for the English Revolution, New York $200_{4}, 63,65,84,179$.

65 T. Edwards, The second part of Gangraena, London 1646 (Wing E.235), $14^{-1} 5$. 
Mans mortalitie was written by Clement Writer, then known for his departure from theological orthodoxy. ${ }^{66}$ Moreover, when Edwards ascribed several political works to Overton in part III of Gangraena, he did not mention The arraignment of $M r$ persecution, a central piece of evidence for the attribution of Mans mortalitie to Richard Overton. ${ }^{67}$

In view of the contemporary failure to identify the author of Mans mortalitie, it would be inappropriate to consider Hobbes's probable use of Mans mortalitie in relation to Overton's other works on toleration or contemporary politics. If Mans mortalitie is taken together with Overton's other political works, it might be possible to discern a link between his Leveller ideas and the doctrine of mortalism, as Nicholas McDowell has done. ${ }^{68}$ Without knowledge of its author, however, it would have been difficult for contemporary readers to infer wider political implications than a direct challenge to the religious orthodoxy at that time from Mans mortalitie, a work dedicated simply to proving the doctrine of mortalism. If Hobbes used Mans mortalitie, he probably read it as a work of scholarly and ingenious scriptural interpretation, as he did Mede's work. Hobbes might also have seen provocative ideas in Mans mortalitie, as he did his own in Leviathan: they were, Hobbes said, 'New and well proved Truth' that could cause no 'disorder in a State' when people called 'not onely for Peace, but also for Truth' 69

This examination, focusing on one of the unusual elements of Hobbes's eschatology, the doctrine of mortalism, has revealed the significant agreement in biblical interpretation found only between Hobbes and Overton. It is now time to turn to another uncommon feature of Hobbes's eschatology, the terrestrial kingdom of God after the last judgement, and to consider scriptural arguments for it.

\section{Hobbes's terrestrial kingdom of God after the Resurrection}

Before discussing Hobbes's scriptural interpretation in Leviathan arguing for the terrestrial kingdom of God after the last judgement, it is useful to clarify the nature of the development of his opinion on this issue from

${ }^{66}$ Edwards, Gangraena, 82; B. W. Ball, 'Clement Writer', ODNB. See also Ball, The soul sleepers, 86-8, and J. Peacey, 'Reviving the radicals: Clement Writer and the historiography of the English Revolution', Prose Studies xxxvi (2014), 243-55.

${ }_{67}$ T. Edwards, The third part of Gangraena, London 1646 (Wing E.237), $14^{8-} 5^{1}$; Overton, Mans mortalitie, pp. xiii-xv; P. Zagorin, 'The authorship of Mans mortallitie', The Library $\mathrm{s}^{-\mathrm{v}}\left(195^{\circ}\right), 183$.

${ }^{68}$ N. McDowell, 'Ideas of creation in the writings of Richard Overton the Leveller and Paradise Lost', Journal of the History of Ideas lxvi (2005), 59-78, and The English radical imagination: culture, religion, and revolution, I630-I660, Oxford 2003, $50^{-}-72$.

69 Hobbes, Leviathan, 'A review and conclusion', 394. 
De cive to Leviathan, a point not addressed by previous studies. In De cive, Hobbes only touched on heaven or the kingdom of God after the Resurrection, regarding them as spiritual matters beyond human reason. $7^{\circ}$ Thus, Hobbes's terrestrial kingdom of God in Leviathan might simply look like a version of his ideas in De cive, elaborated in line with his materialistic philosophy. However, a close reading of De cive indicates that Hobbes did change his opinion about the kingdom of God after the last judgement between De cive and Leviathan.

Hobbes's change of mind can be seen, for example, by paying close attention to a passage in De cive. 'Although the Kingdom of God which is to be established through CHRIST by a new Covenant will be a Heavenly Kingdom, we must not therefore think that those who entered into that Agreement with faith in CHRIST would not need also to be governed on earth.' $7^{1}$ The contrast of 'a Heavenly Kingdom' with a government on earth suggests that, in De cive, Hobbes made the traditional assumption that the kingdom of God in the future would be established in heaven and not on earth, as proposed in Leviathan. Additionally, another illustrative passage in De cive states that in the kingdom of God, there will be no laws 'because laws are given to us by God to direct us to heaven, not in heaven'. $7^{2}$ The contrast between laws directing humans to heaven and the lack of laws in heaven suggests that people will be in two distinct places in this life and in the afterlife. In Leviathan, on the other hand, Hobbes held that people would remain on earth in both cases.

By developing his new idea about the kingdom of God in Leviathan, Hobbes dealt with one political issue not addressed in De cive. Though Richard Tuck found the gist of Hobbes's new eschatology to be liberation from the fear of eternal damnation, the political significance of the terrestrial kingdom of God after the last judgement also needs to be taken into consideration. 73 As illustrated by Hobbes's remark that 'he that pretends to teach men the way of so great felicity, pretends to govern them', the promise of utter happiness in heaven was, in the eyes of Hobbes, the source of clerical power.74 In De cive, while Hobbes minutely discussed the way to heaven or salvation, he left untouched the notion of heaven as the source of clerical power, making a conventional contrast between 'eternal happiness' and 'utter misery for eternity'. 75 In Leviathan, Hobbes certainly maintained the conventional idea that 'Eternall life is a greater reward, than the life present. ${ }^{7}{ }^{6}$ His revised eschatology, however, emphatically denied that the saved, as the subjects of God, would 'ascend to his happinesse any higher than Gods footstool the

$7^{\circ}$ Idem, De cive, xvii.1 $3,28$.

73 Tuck, 'The civil religion', $13^{1-2 .}$

75 Idem, De cive, vi.1 1; xvii. 27 ; xviii. 1 .

${ }^{6}$ Hobbes, Leviathan, ch. xxxviii, p. $23^{8}$.
$7^{1}$ Ibid. xvii.6. $7^{2}$ Ibid. xvii.8.

74 Hobbes, Leviathan, ch. xxxvi, p. 230. 
Earth'.77 This revised view of 'heaven' thus lowered the expectations of the happiness brought by salvation and thereby undermined the basis of clerical power much more pointedly than was done in De cive.

Now that the nature of the change that occurred between De cive and Leviathan has been clarified, the scriptural evidence presented in Leviathan for Hobbes's terrestrial kingdom of God after the last judgement is to be considered. The evidence, on the whole, consists of six parts, one appearing in both chapters xxxv and xxxviii, one in chapter xxxv and the other four in chapter xxxviii. First, in chapters xxxv and xxxviii, Hobbes took literally biblical terms used in the predictions of Old Testament prophets suggesting the place of the kingdom of God in the future, such as 'Jerusalem' and 'Zion'. For example, in chapter xxxv, Hobbes mentioned the passage in Isaiah xxiv.23, 'the Lord of hosts shall reign in mount Zion, and in Jerusalem', and commented that here the prophet 'speaketh expressly of his Reign in Zion, and Jerusalem; that is, on Earth'. $7^{8}$ This inference presupposed Hobbes's interpretation of the words 'Zion' and 'Jerusalem' not in a metaphorical sense but in a literal one. In a similar fashion, when Hobbes discussed the place of salvation in reference to Isa. xxxiii.20-4 in chapter xxxviii, he turned his attention to the expression 'Jerusalem a quiet habitation' and deduced from this that 'Salvation shall be on Earth, then, when God shall reign, (at the coming again of Christ) in Jerusalem.'79

Second, in chapter xxxv, Hobbes seems to have taken Christ's status of 'king' in the New Testament in a literal sense as a ruler of a kingdom: he drew attention to the fact that Jesus was put to death as 'an enemy to Caesar', with the title on his cross being the 'King of the Jews' (John xix.19). ${ }^{80} \mathrm{He}$ also quoted a passage in Acts xvii. 7 , which said, in his wording, that the Apostles 'did all of them contrary to the decrees of Caesar, saying there was another King, one Iesus'. ${ }^{81}$ For Hobbes, 'the kingdom of God' in the New Testament meant 'a Civill Kingdome', just as the term in the Old Testament signified one for the people of Israel. ${ }^{82}$

Third, in chapter xxxviii, Hobbes argued that the expression 'the kingdom of heaven' did not necessarily mean that the kingdom of God was located in heaven. ${ }^{83}$ For him, it simply meant that the throne of the king, God, was in heaven. Fourth, Hobbes discussed biblical passages suggesting that the kingdom of God would come down from heaven instead of going 'up to it from Earth'. ${ }^{4}$ The scriptural verses in question are John iii.13, Acts i.1 1 and Revelation xxi.2, xxi.10. ${ }^{85}$ For example, Hobbes cited a passage in Rev xxi.2: 'I John saw the Holy City, New Ierusalem,

77 Ibid. 240.

8 o Ibid. ch. xxxv, p. 219.

$7^{8}$ Ibid. ch. xxxv, p. 218.

83 Ibid. ch. xxxviii, pp. $240,247$.

$8_{1}$ Ibid.
84 Ibid. 239.

79 Ibid. ch. xxxviii, p. $24^{6}$.

82 Ibid.

85 Ibid. 239, 240. 
coming down from God out of heaven.' ${ }^{86}$ Similarly, in denying that people would ascend to heaven, Hobbes quoted John iii.13: 'No man hath ascended up to Heaven, but he that came down from heaven, even the Son of man, which is in Heaven.' 87 Fifth, Hobbes understood that the paradise in which Adam enjoyed eternal life was located on earth and inferred from this that the kingdom of God in which the saved would enjoy immortality would also be on earth. ${ }^{8}$ Sixth, Hobbes drew attention to Matthew xxii.3o, which states that in the Resurrection, the saved 'neither marry, nor are given in marriage'. ${ }^{89}$ In Hobbes's view, this idea comported with that of the terrestrial kingdom of God because the earth would soon become full if immortal people should procreate. $9^{\circ}$

Among these six points of scriptural argument for the earthly kingdom of God, the first four were made by Archer or Maton, who, in the 1640 , proposed the personal reign of Christ on earth for a thousand years immediately before the last judgement.91 Certainly, both Archer and Maton, unlike Hobbes, envisaged 'heaven' after the last judgement in the traditional sense of the term. Moreover, their terrestrial kingdom would be established before the last judgement, whereas Hobbes's would be established after the last judgement. However, all of them shared the idea of an earthly kingdom of Christ or God at the end of this world. Some of the biblical arguments that Archer or Maton presented for their millennial kingdoms, accordingly, were common to Hobbes's for his terrestrial kingdom of God.

What, then, are the specific points of agreement in scriptural interpretation between Hobbes on the one hand and Archer and Maton on the other? The first point of similarity concerns Hobbes's literal understanding of biblical places referring to the kingdom of God. Though Archer did not explicitly provide a literal interpretation of biblical terms identifying the places of his millennial kingdom, it seems that he shared Hobbes's view that 'God shall reign, (at the coming again of Christ) in Jerusalem'.$^{2}$ This was because, as Archer said, 'at Ierusalem will Christ begin to shew himself' 93 This remark presupposed a literal interpretation of the term 'Ierusalem', as it followed a discussion about the restoration of the city of Jerusalem in his millennial kingdom.94 While Archer argued this issue only briefly, Maton explicitly emphasised the literal interpretation of the

${ }^{86}$ Ibid. 239. $\quad 87$ Ibid. 240. $\quad{ }^{88}$ Ibid. 238-9. $\quad{ }^{89}$ Ibid. 239. $\quad 9^{\circ}$ Ibid.

$9^{1}$ This article does not take into consideration those who expressed such a view in the ${ }_{16} 6_{5}$ os, among whom was John Durant, as they could not possibly have influenced Hobbes's Leviathan. Also note that Maton did not seem to have been influenced by Archer. While Maton often appealed to major millenarians before the $164 \mathrm{os}$, he mentioned Archer only when his critic, Alexander Petrie, associated Maton with Archer: R. Maton, Israel's redemption redeemed, London 1646 (Wing M.1 295), 149-50.

$9^{2}$ Hobbes, Leviathan, ch. xxxviii, p. 246.

93 H. Archer, The personall reign of Christ upon earth, London 1642 (Wing A.3615), 27.

94 Ibid. 
Scriptures, opposing the metaphorical understanding of other interpreters. 95 When he argued that his millennial kingdom would be located on earth, he clarified by saying that it would be in Jerusalem, adding and quoting several scriptural verses making reference to this place. $9^{6}$ This indicates that he interpreted the expression 'Jerusalem' in the scriptural passages literally.

Second, just as Hobbes regarded his kingdom of God as a civil society, so did Archer and Maton their millennial kingdoms. For Archer, the 'monarchical' state of Christ's kingdom was distinct from providential and spiritual states. 97 In this state, Archer said, Christ 'will governe as earthly Monarches have done'. $9^{8}$ Moreover, Archer's kingdom at the end of this world was, like Hobbes's, foreshadowed by the kingdom of Israel in which God ruled as a king. Hobbes argued that what Christ would restore was the kingdom of God originally established for the people of Israel as a civil society in the Old Testament. In a similar way, for Archer, the nation of Israel when God or Christ ruled as a monarch was 'a shadow or Type' of Christ's millennial kingdom.99 Maton was no less clear on this issue than Archer. He accepted the 'faith of the Jewe', which was that Christ 'shall come as a King to reigne on earth, and restore againe the Monarchie of Israel'. ${ }^{100} \mathrm{He}$ characterised this reign as a 'politicke government'. ${ }^{101}$ Like Hobbes in the Latin version of Leviathan, Maton referred to Luke i. $3^{2-3}$ to support his claim of Christ's reign on earth. ${ }^{102}$

Third, assertions similar to Hobbes's that the descriptor 'the kingdom of heaven' did not necessarily mean that the kingdom would be located in heaven were made by both Archer and Maton. Archer argued that Christ's millennial kingdom was 'indeed heavenly, but yet on earth, not in heaven'. ${ }^{103}$ Although Maton distinguished his millennial kingdom from 'the Kingdome of Heaven' after the last judgement, he also associated the terrestrial kingdom with heaven by calling it a 'Heavenly Kingdome'. ${ }^{104}$ It is 'a Kingdom in which men shall live after an Heavenly estate and condition: a Kingdome in which Gods will shall be done, as it is in heaven'. ${ }^{105}$

Fourth, Hobbes's point that several scriptural verses suggested that the kingdom of God would descend from heaven was also made by Archer; he emphasised that Christ's kingdom would come down from heaven, citing Rev. xxi.2 and Acts i.1 1, verses also quoted by Hobbes. ${ }^{106}$ Archer

95 R. Maton, Israel's redemption or the propheticall history of our Saviours kingdome on earth, London 1642 (Wing M.1294), 47-8.

$9^{6}$ Ibid. 57 .

97 Archer, The personall reign, 1-2. Note, however, that Archer did not, as Hobbes did, refer to scriptural passages in the Gospels or the Acts that describe Christ as the king of the Jews and an enemy to Caesar.

100 Maton, Israel's redemption, $\mathbf{1}-\mathbf{2}$.

102 Ibid. 54; Hobbes, Leviathan, ch. xxxv, p. 643 (Malcolm edn).

${ }_{103}$ Archer, The personall reign, $19 . \quad{ }_{104}$ Maton, Israel's redemption, 63.

105 Ibid.

106 Archer, The personall reign, 14 (Rev. xxi.2), 18 (Acts i.11), 19 (Rev. xxi.2). 
also argued, like Hobbes, that nobody but Christ 'ever entered the highest Heavens', though he did not refer to John iii.1 3 as Hobbes did. ${ }^{107}$

Hobbes's scriptural case for the terrestrial kingdom of God, thus, was preceded by that of Archer or Maton for their millennial kingdoms in many ways. Nevertheless, the similarity is not significant enough to claim the influence of Archer or Maton on Hobbes, given the lack of evidence indicating a contextual connection. Maton's work, in particular, was not well known, though it invited criticism from Alexander Petrie and was republished several times. Archer's work, on the other hand, was mentioned not only by various radical Puritans but also by Overton in Mans mortalitie. ${ }^{108}$ Therefore, the possibility of Hobbes's knowledge of Archer's work might not be so different from that of his knowledge of Overton's. In any case, it can safely be said that the scriptural argument for Hobbes's terrestrial kingdom of God after the last judgement did not come out of nowhere.

Here, it would be useful to point out that, setting the arguments of Archer and Maton aside, the idea of the personal and political reign of Christ on earth was unusual even among English millennialists in the first half of the seventeenth century. ${ }^{109}$ Millennialism, the belief that Christ will establish a 1,ooo-year reign of the saints on earth before the last judgement, was proposed by several major figures, such as Thomas Brightman and Joseph Mede, before the Civil War. ${ }^{110}$ Mede, in particular, was mentioned by Hobbes in his later work, though it is not clear whether Hobbes read Mede's work on millennialism. The works of these millennialists were republished or translated in the 1640 os and were widely cited and mentioned by millennialists in this decade. For example, when Thomas Hayne published a work arguing against millenarian ideas in 1645 , he mentioned and criticised the major pre-1640 millennialists together with Archer and The glympse of Sions glory, a work written by the Independent minister Thomas Goodwin. ${ }^{111}$ With the exception of Archer, however, all of the millennialists whom Hanye criticised found the nature of Christ's millennial reign in the glorious state of the Church.

107 Ibid. 25 .

108 B. S. Capp, The fifth monarchy men: a study in seventeenth-century English millenarianism, London 1972, 46; Overton, Mans mortalitie, 39 .

109 On English millennialism in the seventeenth century see B. W. Ball, A great expectation: eschatological thought in English Protestantism to I66o, Leiden 1975, 157-92, and K. R. Firth, The apocalyptic tradition in early Protestant historiography in England and Scotland, I530 to I 655, Oxford 1971, 204-41.

110 On Mede's achievements and influence see J. K. Jue, Heaven upon earth: Joseph Mede $\left(\mathrm{I}_{5} 86-\mathrm{I}_{3} 8\right)$ and the legacy of millenarianism, Dordrecht 2006.

111 T. Hayne, Christs kingdome on earth, opened according to the Scriptures, London 1645 (Wing H.1 217 ). 
Though the 164 os saw the dissemination of millenarian views by Puritan preachers, views resembling those of Archer or Maton remained uncommon. In a study of English millenarianism, Bernard Capp enumerated more than thirty texts published in the 164 os by ministers who could be identified as millenarians in a broad sense, that is, those who discussed topics such as the imminent kingdom of Christ on earth and the AntiChrist. ${ }^{12}$ However, many of them touched on these topics only briefly. ${ }^{13}$ Even when the imminent kingdom of Christ was examined extensively by people such as William Gouge and William Sedgwick, it was, on the whole, interpreted as referring not to a political kingdom but to the Church. ${ }^{14}$ When the personal reign of Christ on earth at the end of the world was specifically mentioned, it was treated only briefly or rejected. ${ }^{115}$ Therefore, it is unlikely that Hobbes could have come across potential sources for his terrestrial and political kingdom of God other than Archer or Maton.

Hobbes's scriptural interpretation for his eschatology in Leviathan is known as one of the most striking aspects of this classic work. It is a contributor to Hobbes's lingering reputation as an 'atheist' and to the scepticism of his sincerity in biblical exegesis. ${ }^{116}$ However, this article has shown that, insofar as the doctrine of mortalism and the terrestrial kingdom of God after the Resurrection are concerned, Hobbes's scriptural case was to a large extent preceded by those of his contemporaries. In particular, his scriptural interpretation for the doctrine of mortalism was probably directly indebted to Mans mortalitie.

This, in turn, suggests what was truly radical in Hobbes's eschatology: the transformation of the meaning and significance of salvation and damnation. Even mortalists like Overton and millenarians like Archer did not question the traditional notions of salvation and damnation as eternal and utter happiness and torment, respectively. ${ }^{117}$ However, Hobbes challenged them by denying 'happinesse any higher than Gods footstool the Earth' for the saved on the one hand and extreme and never-ending

112 Capp, The fifth monarchy men, 38, 46-9.

113 For example, see T. Collier, A vindication of the army-remonstrance, London 1648 (Wing C.5301), sig. A3, and G. Hickes, The glory and beauty of Gods portion, London 1644 (Wing H.1838), 42 .

${ }_{114}$ W. Gouge, The progresse of divine providence, London 1645 (Wing G.1393); W. Sedgwick, Zions deliverance and her friends duty, London 1642 (Wing S.2392).

${ }^{115} \mathrm{~J}$. Burroughs, Moses his choice, London 1641 (Wing B.6094), $4^{8} 5^{-7}$; W. Bridge, Christs coming, London 1648 (Wing B.4451), 6; G. Hughes, Ve-Euge-Tuba, London 1647 (Wing H.3310), 17-18.

${ }_{116}$ For one of the first such reactions to Hobbes's religious views in Leviathan see Henry Hammond's remark in [Anon], 'Illustrations of the state of the Church during the Great Rebellion', The theologian and ecclesiastic, ix, London 1850, 294-5.

${ }_{117}$ Overton, Mans mortalitie, 39-40; Archer, The personall reign, 13-14, 19. 
torment for the reprobate on the other. ${ }^{18}$ In the revolutionary years, certainly, some controversialists questioned the conventional view of damnation. ${ }^{19}$ However, Hobbes was distinct in questioning that of salvation too. It is not surprising, then, that Hobbes's version of eschatology, as part of 'Hobbism', continued to provoke a reaction in the English people well into the Restoration period and beyond. ${ }^{120}$

118 Hobbes, Leviathan, ch. xxxviii, pp. 240, 244-5.

119 C. Hill, The world turned upside down: radical ideas during the English Revolution, London 1991, 170-8. See also Almond, Heaven and hell, 146-55, and D. P. Walker, The decline of hell: seventeenth-century discussions of eternal torment, London 1964, 93, $104-5$.

${ }_{120} \mathrm{~J}$. Parkin, Taming the Leviathan: the reception of the political and religious ideas of Thomas Hobbes in England, I640-I 7oo, Cambridge 2007, 261-2, 392-4. 